\title{
The effect of camel urine on islet morphology and CCL4-induced liver cirrhosis in rat
}

\author{
S Al Neyadi, R Al Jaberi, R Hameed, J Shafarin, E Adeghate \\ From International Conference for Healthcare and Medical Students 2011 \\ Dublin, Ireland. 4-5 November 2011
}

\section{Introduction}

Camel urine has been used for decades as a medication for several ailments in the Middle East. Folklore medicine of the Middle East has shown that, camel urine has a beneficial effect in conditions such as liver cirrhosis.

\section{Methods}

Camel urine was given as a drink daily to normal and treated rats for 4 weeks. Glucose tolerance test was performed at the end of the experiment. Immunohistochemistry was used to determine the percentage distribution of insulin and glucagon immunoreactive cells. $\mathrm{H} \& \mathrm{E}$ stain was used to access liver cirrhosis in control and urine-treated rats.

\section{Results}

The administration of camel urine significantly increased the number of insulin-positive cells in pancreatic islets. CCL4-treated rats did not have impaired glucose tolerance. CCL4 caused vacuolarization of hepatic cells. Rats treated with camel urine have improved hepatic morphology compared to untreated controls.

\section{Conclusions}

The study shows that camel urine may contain bioactive agents capable of preventing CCL4-induced hepatic and pancreatic islet lesions.

Published: 9 July 2012

\section{doi:10.1186/1753-6561-6-S4-P42}

Cite this article as: Al Neyadi et al:: The effect of camel urine on islet morphology and CCL4-induced liver cirrhosis in rat. BMC Proceedings 2012 6(Suppl 4):P42.

$\overline{\text { Department of Anatomy, Faculty of Medicine \& Health Sciences, United Arab }}$ Emirates

(ㄷ) 2012 Al Neyadi et al; licensee BioMed Central Ltd. This is an Open Access article distributed under the terms of the Creative Commons Attribution License (http://creativecommons.org/licenses/by/2.0), which permits unrestricted use, distribution, and reproduction in any medium, provided the original work is properly cited.
Submit your next manuscript to BioMed Central and take full advantage of:

- Convenient online submission

- Thorough peer review

- No space constraints or color figure charges

- Inclusion in PubMed, CAS, Scopus and Google Scholar

- Research which is freely available for redistribution Submit your manuscript at
www.biomedcentral.com/submit
- Immediate publication on acceptance 